methods of putting entomological information before the farmer. This is a point where many of us fail. We get lots of information on a certain problem, publish it and then often send it to the wrong men who throw it into the waste basket or allow it to lie on dusty shelves unread and unused.

Mr. F. M. Webster: In 1891 Dr. C. V. Riley attempted to introduce a European parasite of the Hessian fly. It was placed in the field but little has been heard concerning it up to the present time. The facts concerning its introduction and recovery are given in the following paper by Mr. W. R. McConnell.

\title{
SUMMARY OF FACTS ABOUT THE INTRODUCTION OF PLEUROTROPIS EPIGONUS WALK
}

\section{- By W. R. McConnell}

The species was originally described under the name Entedon epigonus Walker, and apparently is the same as Semiotellus nigripes Lindeman, as Dr. Riley compared specimens with Walker's types. (Forbes, Insect Life, 1892, 73.) The species is now placed in the genus Pleurotropis.

Introduction into America

1891-Riley received infested puparia from Mr. Fred Enock, of London, England, during the spring of that year.

This infested material was distributed to Forbes in Illinois, Cook in Michigan (Agricultural College), and Fletcher in Canada (Ottawa). (Forbes, Insect Life, V, 1892, 73; Riley, Insect Life, 1893, 133-4.)

No report from Cook and Fletcher, as far as I can find.

Forbes (Insect Life, V, 1892, 73) reported rearing adults from the original material in a small enclosed plat experiment, but up to August 15,1892 , had recovered no specimens from fields in which material was distributed. No further statement regarding the success of Forbes' experiments has been found.

1894-Material from Enock placed in field at Fredericktown, Md., and on farm of C. Morgan Eldridge at Cecilton, Md. (Howard, Insect Life, VI, 1894, p. 375.) (Fredericktown must be the Frederick of today.)

No further report from the Fredericktown introduction.

At Cecilton, Md., Ashmead succeeded in sweeping up one $\sigma^{7}$ during May of the next year. (Howard, Insect Life, VII, 1895, 414-5.)

There seems to be no further records until our rearings at Hagerstown began in 1915 .

In the following table is given the record of our rearings at the Hagerstown Laboratory: 
Locality No. of Specimens Reared Collector

Hagerstown, Md........ 14

Andersonburg, $\mathrm{Pa} . \ldots \ldots \ldots \quad 1$

Warfordsburg, Pa........ 1

Montoursville, Pa......... 1

Ford City, Pa.......... 1

Greenville, Pa........... 1
McConnell and Myers Myers

Myers

Myers

McConnell

McConnell

Total .

19 specimens

All of the localities except the last two are east of the Allegheny Mountains. Ford City, Pa., is on the Allegheny River, and Greenville is on the western edge of Pennsylvania.

We know practically nothing of its life-history, as I have never succeeded in inducing it to oviposit. Adults have emerged in cages from April to June inclusive and from September to December inclusive. Most of the specimens reared were males.

\section{IMPORTANCE}

Riley stated that it was introduced because it was more abundant in England and far more beneficial than any of our native species. Enock was probably his authority for conditions in England. His statement for this country seems very doubtful, in view of the scarcity of the species. It may not be adapted to the climate, and again it may become very abundant during a widespread outbreak of the Hessian fly. The latter point of view is probably more nearly ccrrect, since it seems to be able to maintain itself over periods when the host is scarce, in spite of the predominance of males.

\section{LIST OF REFERENCES}

1891. Forbes, S. A., Insect Life, Vol. IV, pp. 179-81.

1891. Rruex, C. V., Report of the U. S. Entomologist (not seen).

1892. Forbes, S. A., Insect Life, Vol. V, p. 73.

1893. Riley, C. V., Insect Life, Vol. VI, pp. 133-4.

1894. Howand, L. O. (?), Insect Life, Vol. VI, p. 375.

1895. Howard, L. O. (?), Insect Life, Vol. VII, pp. 356-7.

1895. Howard, L. O., Insect Life, Vol. VII, pp. 414-15.

1895. Marlatt, C. L., Circular No. 12, N. S., Division of Entomology, U. S. Department of Agriculture.

1898. Osborn, H., Bulletin No. 16, N. S., Division of Entomology, U. S. Department of Agriculture, pp. 38-41.

1901. Mardatt, C. L, Farmers' Bulletin No. 132, U. S. Department of Agriculture, pp. 13-22.

1902. Felt, E. P., 17th Report State Entomologist of New York, Bulletin No. 53, New York State Museum, pp. 699-925.

Hagerstown, Md., December 22, 1915. 
President Glenn W. Herrick: The next paper on the program is by R. R. Parker of Montana. As the author is not present the paper will be read by J. R. Parker.

\section{DISPERSAL OF MUSCA DOMESTICA LINNAUS UNDER CITY CONDITIONS}

By Ralph R. Parker, Bozeman, Mont.

(Not received in time for publication in this issue)

President Glenn W. Herrick: Is there any remark or discussion?

Mr. MAX Kislink, JR.: I have been working on dispersion of the house-fly for the Bureau of Entomology. At the Animal Industry Farm at Bethesda, Md., we liberated from the 30th of June to September 10, 200 colored flies. All were liberated from about the same point on this farm. We bred these in cages from a lot of maggots taken from pig manure.

The method of coloring was with colored chalk and marking freshly emerged flies, not more than a day old. First we put traps within 500 yards from the point we liberated the flies and caught a good many in that way. Then we increased the distance. We also made rounds among the residents and whenever they saw a colored fly they would swat it. Some people who were not notified of it thought the flies were carriers of a certain kind of spotted fever. The results of the summer showed that the flight spread out over an area of one and a quarter miles. In the experiment I noted that the flies did not go in any particular direction with the wind. In fact I have often noticed the flies going against the wind.

President Glenn W. Herrick: Did you put the chalk on their wings or on their bodies?

Mr. Max Krsuink, Jr.: As soon as the flies emerged we let them out of the breeding cages into a trap. Then we put the flies into paper bags heavily chalked, shook them up and when they were let loose there was quite a cloud of color.

President Glenn W. Herrick: For the past three years I have been spending a part of the summer on Cranberry Lake in the Adirondacks, one and one-eighth miles from the village of Cranberry Lake. There are no animals on that side of the lake but toward the latter part of the summer we are troubled with house-flies. There are no breeding places for them and they must come from the village one and one-eighth miles across the lake in a diagonal direction. I see no 